\title{
Countering the commercial determinants of health: strategic challenges for public health
}

\author{
Becky Freeman ${ }^{a, b, d}$ and Colin Sindall $\left.\right|^{b, c}$ \\ a School of Public Health, Sydney Medical School, University of Sydney, NSW, Australia \\ b Guest Editor, Public Health Research \& Practice, Issue 3, 2019 \\ c Independent Health Policy Consultant, Melbourne, Victoria, Australia \\ ${ }^{d}$ Corresponding author: becky.freeman@sydney.edu.au
}

\section{Article history}

Publication date: September 2019

Citation: Freeman B, Sindall C. Countering the commercial determinants of health: strategic challenges for public health. Public Health Res Pract. 2019;29(3):e2931917. https://doi.org/10.17061/phrp2931917
Private enterprise is widely seen as making a positive contribution to societal wellbeing. In 2018, more than $80 \%$ of Australians were employed in the private sector. ${ }^{1}$ Commerce and industry - from small business to large corporations - generate wealth, drive technological innovation, and provide products and services that the community values. However, when the regulation of commercial practices is weak - particularly in the case of large corporations - chasing profits can trump public welfare. The findings of the Royal Commission into Misconduct in the Banking, Superannuation and Financial Services Industry aptly illustrate this conflict, concluding that "much if not all of the conduct identified in the first round of hearings can be traced to entities preferring pursuit of profit to pursuit of any other purpose."'

The focus of this special issue on the "commercial determinants of health' is on the corporations which produce and market unhealthy commodities such as tobacco, alcohol, soft drinks and processed food. The limited regulatory control of these industries has contributed to their role in driving the growing global epidemic of noncommunicable disease. The papers commissioned for this issue help to further illuminate how the behaviour of these companies serves to undermine advances in chronic disease prevention.

In this, we have been guided by Kickbusch et al's widely cited definition of the commercial determinants of health as "strategies and approaches used by the private sector to promote products and choices that are detrimental to health". ${ }^{3}$ This terminology reflects the increasing global understanding of how unhealthy commodity industries affect health, and is the term favoured by the World Health Organization (WHO) and other United Nations agencies.

In using the commercial determinants of health framework, we also acknowledge the discussion in the literature of the 'corporate determinants of health' and the recent body of research on transnational corporations..$^{4-9}$ This work recognises the wider impact of major corporations on health and wellbeing, beyond the manufacture and marketing of commodities. This framing considers both the direct and indirect effects of corporate operations, including through the production process, environmental footprint, employment and remuneration practices, financial practices (such as meeting tax obligations) and political behaviour. ${ }^{10}$

Kickbusch et al proposed that there would be value in using the commercial determinants of health banner as a multidisciplinary field to 
conceptually unite all critical public health analysis concerned with corporate power and the role of corporations in propagating the noncommunicable diseases pandemic. ${ }^{3}$ This was a welcome and timely call. Systematising efforts - in research, theory and practice in confronting the producers of unhealthy commodities is crucial. But in sharpening a focus on the corporation as a 'disease vector'11, the public health community will need to forge stronger links with colleagues in areas such as law, economics, corporate finance and political science, and with civil society organisations.

To date, perspectives on the role of the private sector in shaping public health reforms have been mixed, with some critical voices urging caution and exclusion of vested corporate interests in policy making, while others have urged close partnerships to create mutually beneficial solutions. The rise of smoking and the role the tobacco industry played in not only selling cigarettes, but in actively deceiving the public about the true harmfulness of cigarettes, laid a clear path for excluding the tobacco industry from public health policy making. This exclusion is enshrined in the WHO Framework Convention on Tobacco Control (Article 5.3), which requires all convention parties to protect public health from tobacco industry interference. ${ }^{12}$ These same protections are not afforded from other harmful industries and this is reflected in the slow progress of other prevention efforts when compared to the success story of tobacco control.

As the food and beverage industries have aggressively expanded the promotion and sale of their unhealthy products globally, a sharper focus has developed on the operations and practices of the corporations driving these processes. Although the severity of the health impact of tobacco is unique, the tactics used by other industries to block, divert, and delay health reforms are near identical to those embraced by the tobacco industry. The structural linkages and interlocking directorates across industries mean that differentiating 'Big Tobacco' from other global corporate interests in 'Big Food', 'Big Soda' or 'Big Alcohol' becomes increasingly challenging. ${ }^{13}$ The case for 'tobacco industry exceptionalism' is further weakened when there is little evidence to suggest that the strategies deployed by the food and beverage companies are any more likely to produce positive health outcomes. ${ }^{14}$

Kickbusch et al propose a number of key pathways through which health-damaging corporations exert strategic influence on consumption patterns and public policy. ${ }^{3}$ These include:

- Marketing, which enhances the desirability and acceptability of unhealthy commodities

- Lobbying, which can impede policy barriers such as plain packaging and minimum drinking ages

- Corporate social responsibility strategies, which can deflect attention and whitewash tarnished reputations

- Extensive supply chains, which amplify company influence around the globe.
Responses to these strategies are challenging as they inevitably require a stronger role for the state in regulating corporate behaviour. While often touted as effective solutions by industry, self-regulation, public health education and policy-making partnerships have had minimal impact on improving the commercial determinants of health. This is unsurprising when voluntary regulations lack any meaningful enforcement, education is drowned out by omnipresent product marketing and policy-making partnerships often result in regulations that heavily favour industry rather than consumer health. ${ }^{15}$

Yet public health voices calling for regulation or use of fiscal measures often gain limited traction, notwithstanding the available evidence. Challenges for public health in this regard include the value placed by governments on the economic contribution of major companies and the jobs provided, industry lobbying power and the dominant media narrative, shared by many politicians, that regulation or taxation applied to specific industries or products constitutes unnecessary 'nanny state' interference in market dynamics or consumer choice.

The papers in this special issue provide important new insights on a number of these areas, in regard to corporate behaviour ${ }^{16}$ and relationships with government ${ }^{17,18}$, media framing of issues ${ }^{19}$ and strategies to bring about change. ${ }^{20,21}$

We believe these papers can help inform how we move forward on these issues. We welcome the debates and new thinking that the commercial determinants framework provides. But ultimately these ideas need to translate into concrete political action as we have seen with tobacco control. How to achieve this is a question to which we hope our readers will give serious consideration.

We hope readers enjoy these themed papers and all the articles in this special issue. We sincerely thank all the authors for their insightful and excellent contributions. We are also grateful to the peer reviewers, who helped further improve what were already high-quality efforts by the authors.

\section{Acknowledgements}

BF has received research grants from the Australia Indonesia Centre and Australian Government during the writing of this manuscript. Outside the submitted work, she reports grants from Australian Government Department of Health, NSW Department of Health, Cancer Institute NSW and National Health and Medical Research Council and has received personal fees from WHO, Asian Center for WTO \& International Health Law and Policy, National Taiwan University, College of Law and from Department of Health, the Government of Hong Kong Special Administrative Region. 


\section{Peer review and provenance}

Internally peer reviewed, invited.

\section{Competing interests}

None declared.

\section{Author contributions}

BF and CS contributed equally to writing and editing the manuscript.

\section{References}

1. Australian Bureau of Statistics. Summary: employee earnings and hours, Australia, May 2018. Canberra: ABS; 2018 [cited 2019 Sep 12]. Available from: www.abs.gov. au/AUSSTATS/abs@.nsf/productsbyCatalogue/27641437 D6780D1FCA2568A9001393DF?OpenDocument

2. Hayne KM. Interim report: Royal Commission into Misconduct in the Banking, Superannuation and Financial Services Industry. Canberra: Commonwealth of Australia; 2018 [cited 2019 Sep 12]. Available from: financialservices.royalcommission.gov.au/Documents/ interim-report/interim-report-volume-1.pdf

3. Kickbusch I, Allen L, Franz C. The commercial determinants of health. Lancet Glob Health. 2016;4(12):e895-e6.

4. Rochford C, Tenneti N, Moodie R. Reframing the impact of business on health: the interface of corporate, commercial, political and social determinants of health. BMJ Glob Health. 2019;4(4):e001510.

5. Millar JS. The corporate determinants of health: how big business affects our health, and the need for government action! Can J Public Health. 2013;104(4):e327-9.

6. Jahiel RI. Corporation-induced diseases, upstream epidemiologic surveillance, and urban health. J Urban Health. 2008;85(4):517.

7. Freudenberg N, Galea S. The impact of corporate practices on health: implications for health policy. J Public Health Pol. 2008;29(1):86-104.

8. McKee M, Stuckler D. Revisiting the corporate and commercial determinants of health. Am J Public Health. 2018;108(9):1167-70.

9. Baum FE, Sanders DM, Fisher M, Anaf J, Freudenberg N, Friel S, et al. Assessing the health impact of transnational corporations: its importance and a framework. Global Health. 2016;12(1):27.
10. Anaf J, Baum F, Fisher M, London L. The health impacts of extractive industry transnational corporations: a study of Rio Tinto in Australia and Southern Africa. Global Health. 2019;15(1):13.

11. Gilmore AB, Savell E, Collin J. Public health, corporations and the new responsibility deal: promoting partnerships with vectors of disease? J Public Health. 2011;33(1):2-4.

12. World Health Organization. Geneva: WHO; 2019. Tobacco free initiative: Article 5.3 of the WHO Framework Convention on Tobacco Control; 2003 [cited 2019 Sep 16]. Available from: www.who.int/tobacco/wntd/2012/ article_5_3_fctc/en/

13. Collin J, Plotnikova E, Hill S. One unhealthy commodities industry? Understanding links across tobacco, alcohol and ultra-processed food manufacturers and their implications for tobacco control and the SDGS. Tob Induc Dis. 2018;16(Suppl 1):A80.

14. Collin J. Tobacco control, global health policy and development: towards policy coherence in global governance. Tob Control. 2012;21:274-80.

15. Martin L. Unhealthy products are gaming flawed health star food rating, study finds. Sydney: The Guardian; 2019 May 30 [cited 2019 Sep 16]. Available from: www. theguardian.com/australia-news/2019/may/30/unhealthyproducts-are-gaming-flawed-health-star-food-ratingstudy-finds

16. Freeman B, Hefler M, Hunt D. Philip Morris International's use of Facebook to undermine Australian Tobacco control laws. Public Health Res Pract. 2019;29(3):e2931924.

17. Robertson NM, Sacks G, Miller PG. The revolving door between government and the alcohol, food and gambling industries in Australia. Public Health Res Pract. 2019;29(3):e2931921.

18. Firth V, Freeman B. Interview with Verity Firth: commercial interests and public health policy. Public Health Res Pract. 2019;29(3):e2931918.

19. Chau JY, Kite J, Ronto R, Bhatti A, Bonfiglioli C. Talking about a nanny nation: investigating the rhetoric framing public health debates in Australian news media. Public Health Res Pract. 2019;29(2):e2931922.

20. Schram A, Townsend B, Youde J, Friel S. Public health over private wealth: rebalancing public and private interests in international trade and investment agreements. Public Health Res Pract. 2019;29(3):e2931919.

21. Watson WL, Martin J. Countering commercial interests: building advocacy campaigns to protect children from food marketing. Public Health Res Pract. 2019;29(3):e2931923.

\section{Copyright: (C) (i) (2) (2)}

(C) 2019 Freeman and Sindall. This article is licensed under the Creative Commons Attribution-NonCommercial-ShareAlike 4.0 International Licence, which allows others to redistribute, adapt and share this work non-commercially provided they attribute the work and any adapted version of it is distributed under the same Creative Commons licence terms. See: www.creativecommons.org/licenses/by-nc-sa/4.0/ 